\title{
A Critical Reflection on Eportfolio as a Teaching Tool
}

\author{
New Zealand Journal of Teachers' Work, Volume 12, Issue 2, 115-130, 2015
}

\author{
LYN LEWIS \\ School of Education \\ Auckland University of Technology
}

\begin{abstract}
Eportfolios are used in early childhood, primary, secondary and higher education settings in New Zealand. While it is common practice to use the tool functions for the storage and presentation of learning, the use of eportfolio as a pedagogy is less well established. This article focuses on the author's use of the Mahara eportfolio with primary students in an initial teacher education programme. Four critical reflective lenses are used to explore eportfolio in three learning activities: developing metacognitive skills through standards-based activities; journalling for attitudinal awareness; and expressing learning through visual narrative in an eposter. An argument is made for a shift in focus from eportfolio as a tool, towards its pedagogical capabilities. While the context of practice is higher education, the eportfolio pedagogies can be transferred to early childhood, primary or secondary contexts.
\end{abstract}

\section{INTRODUCTION}

Eportfolio is commonly used as a tool for its storage and presentation capabilities; however, its pedagogical capability for learning is increasingly a focus in the literature. Stefani, Mason and Pegler (2007) state that eportfolio has the potential to be transformational in learning; Peet et al. (2011) suggest that eportfolio has the capability to develop 21st-century learning skills such as flexibility and integrative thinking; while Eynon, Gambino and Török (2014) claim eportfolio makes learning visible through the reflective process.

In New Zealand, eportfolios are used in initial teacher education programmes for the purposes of student learning, as well as for transfer to future centre/classroom practice. This article focuses on the use of the Mahara eportfolio in the Bachelor of Education (primary) programme at the Auckland University of Technology (AUT), where it is used in theory and professional practice papers. The author has been involved in the introduction and use of this eportfolio since 2009, and shares learning activity examples from her practice (henceforth, first person will be used).

The purpose of this article is to present my practitioner's experience of eportfolio using a critical reflection framework (Brookfield, 1995) to highlight different perspectives on the practice. An argument is developed in support of eportfolio as a tool and a pedagogy for student learning. 


\section{THE NATURE AND PURPOSE OF EPORTFOLIO IN LEARNING}

The definition of electronic portfolios (eportfolios) presented by the Joint Information Systems Committee (JISC, 2008) is used in this article as it highlights eportfolio as both a product (tool) and a process (pedagogy), as well as alluding to its range of capabilities:

An eportfolio is the product, created by the learner, a collection of digital artefacts articulating experiences, achievements and learning. Behind any product or presentation, lie rich and complex processes of planning, synthesising, sharing, discussing, reflecting, giving, receiving and responding to feedback. These processes - referred to here as 'eportfolio-based learning' - are the focus of increasing attention, since the process of learning can be as important as the end product. (JISC, 2008, p. 6)

The product and process approach to eportfolio use should not be regarded as mutually exclusive but rather as complementary. Their relationship defines the type of eportfolio developed. Most early adopters seize on the storage or repository function associated with artefacts related to summative assessment. This results in eportfolio as product in a presentation, celebration or showcase eportfolio (Barrett, 2010; Matthews-DeNatale, 2013). Where the focus is on the reflective capacity of eportfolio for formative assessment, a learning, working or development eportfolio results (Barrett, 2010; Gerbic \& Lewis, 2011). Such an eportfolio can include social interaction and learning within a community of practice (Eynon et al., 2014). The combination of process and product can involve a uniquely personal integration of learning into an integrated knowledge eportfolio (Peet et al., 2011), which incorporates metareflection on a range of learning experiences across contexts and time.

Eportfolio learning is associated with a constructivist orientation in which learners construct meaning from their experiences, both individually and within a social context (Merriam, Caffarella, \& Baumgartner, 2007). The teacher's role is to facilitate such learning through the provision of learning activities which utilise the capability of eportfolio for different ways of thinking, some examples of which I will illustrate in this article.

In higher education, eportfolio has been popular as a tool used to record accountability of student learning, particularly against a graduate profile or externally-imposed professional standards (Emmett, Harper, \& Hauville, 2006; Lewis \& Gerbic, 2012a; Milman, 2005). More recently, eportfolio has come to be recognised for its pedagogical contribution towards supporting 21st-century aspirations for students to be flexible, adaptive, reflective, integrative, creative and critical thinkers (Peet et al., 2011) as well as self-directed, self-managed and self-assessing in their learning (Ring \& Foti, 2006).

Unfortunately, many educators continue to use eportfolio as an electronic repository for achievement outputs which are not created through eportfolio processes. In such a case, eportfolio is usually an 'add on' to an existing learning activity, rather than the focus of the activity. This article will be of interest to those educators who work with eportfolio and wish to move beyond using it only for storage. 


\section{BROOKFIELD'S CRITICAL REFLECTION MODEL}

While there are a range of reflective models suitable for practitioner reflection (Boud, 2001; Boud, Keog, \& Walker, 1985; Moon, 1999; Shön, 1983), I have decided to use Brookfield's (1995) four lenses, which provide a framework offering a range of perspectives on a learning activity. These lenses have been researched in the context of classroom teaching (Brookfield, 1998; 2002,) and shown to uncover taken-for-granted assumptions about professional practice. Brookfield (1995) describes the concept of critical thinking as "hunting assumptions" (p. 2) that frame pedagogical practice. Furthermore, Brookfield (1998) argues that critical reflection cannot be done as a solitary activity, as the filters we apply in personal reflection are themselves based on our assumptions. He warns of a darker side to critical reflection in the risks associated with critiquing taken-for-granted assumptions (Brookfield, 1994). He names these as imposter syndrome (the vulnerability teachers may feel about their competency); cultural suicide (the risk of being marginalised by colleagues when cultural norms are questioned); lost innocence (the epistemological risk of realising that there are no final solutions to the dilemmas of teaching); and road running (the experience of incremental fluctuations of insight, with periods of falling back into old habits). Despite these risks, Brookfield (1995) strongly recommends critical reflection as it informs and justifies decisions and actions related to practice.

His theoretical model of critical reflection (1995) proposes four complementary lenses as mirrors, each reflecting a different perspective and thus supporting a critical interrogation of the experience.

1. Critically reflective lens one: Autobiographical experiences of learning involves viewing the experience through our own lens as a learner, evaluating our pedagogical choices as being influenced by our own positive or negative learning experiences, the associated beliefs and emotions of which can be a default in the way we teach.

2. Critically reflective lens two: Learners' eyes reveal how students have experienced our teaching intentions and the meaning they make of our pedagogical practice. Such feedback is valuable for evaluation of ongoing practice and helps us become more responsive in our planning for learning.

3. Critically reflective lens three: Our colleagues' experiences explored through professional conversations can reflect for us our own actions, offering opportunities to check or reframe our theories of practice. Brookfield (1994) believes that, if this is a safe shared space, the ability to air concerns or issues can be a way of mitigating some of the risks associated with critical reflection.

4. Critically reflective lens four: Theoretical literature presents a lens with multiple perspectives enabling the individual experience to be named in relation to a body of knowledge. Brookfield (2002) suggests that teachers with a sense of impostership or vulnerability about their competency can find comfort in supporting literature. 
These lenses will provide the framework within which I will explore three eportfolio learning activities. The data informing each lens is drawn from a number of sources. The autobiographical lens is a personal reflection on practice and is acknowledged to be subjective. During the first iteration of learning activity 3 (explained below) in 2012, I engaged in a self-study involving systematic intentional inquiry (Brannick \& Coghlan, 2007) into my own practice. This involved regular journal entries over the course of the semester with particular in-depth reflections at 'nodal moments' (Bullough \& Pinnegar, 2001) of professional learning such as a group workshop session and a spontaneous group sharing session. This self-study experience has since been published (Lewis, 2013).

Data for the student lens is drawn from three qualitative research projects each focussed on student perspectives of learning through eportfolio. A similar interpretivist methodology was used in each, based on a constructivist approach where reality is considered to be complex and multi-faceted, in which each person constructs their understanding both individually and within a broader social-learning context. The three projects differed in their focus : Student perspectives of ePortfolios (2009); Student perspectives of learning during a more mature phase of eportfolio use (2011); and Eportfolio and curriculum design: Student and lecturer perspectives (2013). Data were collected through survey questionnaires and focus groups. The number of participants in the surveys was of a reasonable size for analysis (56 in 2009; 94 in 2011; 53 students and 5 lecturers in 2013); while the focus group numbers were smaller (14 in 2009; 20 in 2011; 7 students and 4 lecturers in 2013) but yielded rich data. These research findings have been previously reported (Gerbic \& Lewis, 2011; Lewis, 2014; Lewis \& Gerbic, 2012a, 2012b). The data for the collegial lens arises mainly from informal professional conversations with colleagues on the learning activities as well as research data collected in the 2013 project. Finally, data for the fourth lens is drawn from the theoretical literature in the field of eportfolio both nationally and internationally.

\section{Learning activity 1: Using eportfolio to develop metacognitive skills through a standards-based activity}

Based on a behaviourist approach to learning and teaching (Merriam, Caffarella, \& Baumgartner, 2007), student work is often framed within achievement criteria which require students to provide evidence of meeting set learning outcomes. Initial teacher education students in New Zealand are required to meet a set of externally imposed Graduating Teaching Standards (GTS) (Education Council, 2007). Three Standards (professional knowledge, professional practice, and professional values and relationships) are subdivided into 29 discrete standards, each relating to an aspect of the programme of study. Most providers would expect student teachers to be able to demonstrate their achievement of each of these standards prior to graduation.

In the AUT Bachelor of Education (primary) programme, students have a GTS focus in each practicum experience. This standards-based activity requires students to self-appraise their achievement of a specific GTS in a reflective statement, and to provide an artefact as supporting evidence (such as associate teacher feedback, copies of student work, lesson planning sheets or anything the student can justify as evidence). 
This, the first learning activity, was designed at the time of the introduction of eportfolio in the programme in 2009. It made sense to use the tool function for storage in preparation for student presentation of their achievement of the GTS in a student-lecturer conference at each year end of their programme.

\section{Critical reflection using an autobiographical lens}

As my learning around eportfolio capability has progressed, I have become aware that learning activity \# 1 limits the use of eportfolio to that of a repository or storage tool for presentation purposes, stopping short of enhancing learning. What assumptions led me to design such a behaviourist activity in eportfolio when the learning tool supports constructivist learning? Reflecting on myself as a learner, I realised that I had experienced a behaviourist learning environment in the past: teacher-directed, highly structured and with little room for creative or critical thinking. As a teacher, I have imposed these assumptions about learning on a new generation of learners.

In addition, though I was impressed with the notion of eportfolio, my taken-for-granted assumption was that we could use it as an 'add-on' to ensure that the GTS were achieved. This mistaken assumption could explain why students were unable to identify or articulate the metacognitive processes involved in this learning activity. Skills such as goal-focussed thinking, relating and evidencing, integrating learning, analysing and synthesising remain hidden within what is, in essence, a tick-box activity.

As my experience with eportfolio has grown, I realise that the pedagogical purpose of this learning activity should consider the question 'so what?' Rather than a focus on the fragmented sub-standards of the GTS, a more holistic view of these Standards would involve the student in constructing meaning from other perspectives, such as that of the learner, the community and the broader socio-cultural and political context of New Zealand.

\section{Critical reflection using the learners' lens}

Findings from the three research projects indicated that students focus on the eportfolio as a tool in learning activity \# 1 . While some value its portability and ease of electronic submission from remote settings, others complain of the technology being clumsy, slow and unreliable. A number of early users questioned the value of using eportfolio when hardcopy submission would have been easier. Some students acknowledged, nevertheless, the GTS learning experience as an effective way to record their achievement of the Standards. One student noted that "finding evidence that you are actually capable of doing it (GTS), that was a little bit new... while I'm on practicum, l've got to think about what I will use as evidence later". Another student valued the authentic link between the GTS and becoming a teacher: "I think it sort of guided you towards what you were trying to achieve from teacher education...having this assignment allowed us to use those standards as our goals and enhance our teaching practice". Most of the positive comments related to the learning activity itself, rather than the role of the eportfolio in supporting learning. 
Critical reflection using the lens of colleagues

A number of colleagues who worked with eportfolio in learning activity \# 1, simply followed the established process. Lecturer views on eportfolio (collected during the 2013 research project) reflected an acceptance of eportfolio as a tool, but a lack of engagement with its possibilities as pedagogy: "using them to store files is efficient but unexciting" and, "I believe it engages the students, it provides a platform for them to celebrate their work, it is convenient for submitting assignments, it gets rid of huge amounts of paper and it helps students build a portfolio of their journey through the programme". One lecturer stated: "I don't think it had any impact on student learning", while another said, "I wouldn't say it has greatly affected learning but it is a useful presentation tool".

\section{Critical reflection using the lens of theoretical literature}

Eportfolios are commonly used for evidencing achievement of paper learning outcomes, graduate attributes, or externally-imposed sets of professional standards required by graduates for registration purposes (Milman, 2005; Ring \& Foti, 2006). Such eportfolios are usually summative in nature and are associated with documentation or directed portfolios, following structured templates in which files are uploaded to demonstrate achievement of the standards (Matthews-DeNatale, 2013).

Significant learning has been noted in the literature from this summative use of eportfolio. Ring and Foti (2006) report in their study that students expressed an increasing awareness and understanding of the expectations and standards of the profession when working in-depth with the external teaching standards. Pelliccione and Dixon (2008) note that students' analytical skills related to their personal link with practice deepened, and they were better able to articulate such learning and thus understand themselves as professionals. Other skills identified through using eportfolio for standards-based assessment include critical thinking and linking theory to practice (Wetzel \& Strudler, 2006) and goal-focussed thinking, evidencing and relating (Lewis \& Gerbic, 2012a).

Gathercoal et al. (2007) argue that opportunities exist in moving away from the summative and compliance nature of such portfolios to focus on the holistic development of professional learning, the process of which includes deep reflection, self-knowledge and personal professional growth. Hallam and Creagh (2010) would agree that during the process of self-appraisal students draw on their values and beliefs as they consider professional strengths and weaknesses.

\section{Evaluation of this learning activity based on the critical reflection model}

Using eportfolio as a repository limits students' learning to a focus on the product. This is revealed through the autobiographical, learner and collegial lenses. The literature, on the other hand, demonstrates deep learning associated with standards-based activities, particularly those that link to students' professional practice. My conclusion, based on this critical reflection, is that this learning activity can be altered to include a deeper personal narrative based on a constructivist approach. A more holistic approach to the GTS could include reflective questions for student teachers to consider such as: 'why are these Standards important for a teacher and teaching in New Zealand?' and 'what individuals, groups or other influences have impacted on your 
learning/insights in working with these Standards?' The shift from using eportfolio as a repository and tool for learning towards its pedagogical capability for learning through reflective writing and integrating knowledge gained across the programme would result in deeper learning, while still demonstrating achievement of the GTS.

\section{Learning activity 2: Journalling through eportfolio for attitudinal awareness}

The journal tool within the Mahara eportfolio offers opportunity for ongoing reflective writing. The purpose of this learning activity was for students to engage in journalling in order to articulate their thoughts to reveal their beliefs, attitudes and underlying assumptions. The eportfolio is used for constructivist learning as students make sense of the learning experience, draw on related class discussion and seek literature support for argument developed in the journal entry.

Learning activity \# 2 is part of a paper entitled: Teaching children from diverse ethnicities, intended for student teachers to study diversity in multicultural New Zealand classrooms. The paper aims for students to confront stereotypes and prejudices, raise awareness of their views on multi-ethnic issues, ethics and challenges and to process these so behaviours can be responsive rather than reactive. The paper is seeking attitudinal awareness and the eportfolio journal activity is aligned with this purpose.

At the end of each session, students are asked to journal their response to a provocative statement related to the lecture content; for example, 'reflect on your attitudes towards immigrants from different parts of the world, trying to delve deeply into why you hold such views', or 'how does a teacher assimilate an immigrant child into the classroom culture?' I provide formative feedback on the first journal entry offering suggestions for deeper reflection. At two further milestones in the paper, students are required to request feedback on selected journal entries from a peer. The purpose of this social pedagogy is for students to author their work as well as draw on wider understandings and different perspectives from within the group. Using feedback where relevant, refinement of journal entries is encouraged and final assessment consists of the submission of three self-identified pieces of reflective writing from the eight journal entries.

\section{Critical reflection using an autobiographical lens}

In reflecting on my assumptions about why and how students might learn through this activity, I hold to my conviction that the recording of thoughts in journal form will surface beliefs (and related behaviours). Once there is an awareness or insight into the beliefs and attitudes underlying behaviours, learners have an opportunity to process and act on the learning. I realise this comes from my core value of integrity and honesty as I make the assumption that young students are accurate readers of teacher beliefs and behaviours. Palmer (1998) states, "we teach who we are" (p. 1). Initial teacher education offers an opportunity for students to consider who they are in this respect and to reflect on the messages they will convey through their behaviours.

My assumption for using the journal tool in eportfolio reflects my belief that learners, presented with a visual record of sequenced reflections, will be 
made aware of the progression of their thinking over time, which in turn supports attitudinal awareness.

\section{Critical reflection using the learners' lens}

This paper (Teaching children from diverse ethnicities) received the highest ranking from students in the 2013 research project when $79 \%$ stated that it had enhanced their learning. Attitudinal awareness is confirmed by a student who remarked on the visual progression over time: "I could look back over the course of the paper at the weekly journals and see how my views had changed or strengthened". Another referred to the value of the formative feedback to "promote further and deeper thinking", while another recognised the social pedagogy involved: "it allowed for a collaboration of ideas". Motivation is high as noted by a student who is was pragmatic about the learning experience:

I was actually engaged, I knew at the end of this lecture I had to have this knowledge to construct the journal entry...I was paying a little more attention and got much more out of that paper...so it was actual authentic learning rather than just forced essays.

\section{Critical reflection using the lens of colleagues}

In sharing my perception of the success of this activity with a colleague, the comment was made that I sounded evangelical and lacked a critical perspective. Brookfield (1995) would classify this as an example of cultural suicide, as I had assumed that others would share my enthusiasm for eportfolio as a pedagogy for learning; instead, I was left feeling marginalised and misunderstood. The comment did provoke me to take a more objective stance and, on reflection, I realised that there was more of a balance in the class response, for while many students did demonstrate insight triggered by the activity, others admitted to doing what was required of them to meet the learning outcomes.

\section{Critical reflection using the lens of theoretical literature}

Reflective journalling through eportfolio is well supported in the literature. Parkes, Dredger and Hicks (2013) declare, "we believe that reflection is at the heart of the eportfolio, as it most clearly shows us what our students think about what they are learning" (p. 102). Reflection can trigger an awareness of self (Oakley, Pegrum, \& Johnston, 2014), construct meaning from an experience (Parkes et al., 2013), connect to other meaningful experiences, ideas or theory (Peet et al., 2011) and move from surface to deeper levels of thinking (Doig, Illsley, McLuckie, \& Parsons, 2006). Baxter Magolda (2014) talks of selfauthorship as students consider their sense of 'self' when presenting themselves to an audience for feedback and in turn evaluate the feedback in relation to the identity and positioning of the 'self'. Thus, social pedagogy (Bass, 2014 ) is a significant dimension in the learning process. This learning activity relates strongly to Eynon et al.'s (2014) reflection as a social pedagogy (sharing with authentic others to provide critical feedback) and reflection as an attitude towards change (in cognitive and affective domains), involving "openness, curiosity and a readiness to reconsider long-held ideas about oneself and the world" (p. 99). 
Evaluation of this learning activity based on the critical reflection model

Part of the success of this activity is due to the constructive alignment (Biggs, 1999) of paper learning outcomes for attitudinal awareness with the choice of the eportfolio journal function and the related learning activity. This is reflected through the learner lens as a purposeful and authentic learning experience. The capability of eportfolio to visually display a set of reflections on one page, and to share views for the purpose of professional feedback evidences its use as both a tool and a pedagogy. The literature lens adds weight to my underlying assumption that reflection (in association with eportfolio) can lead to attitudinal insight. Thus, the cultural suicide which I experienced has been moderated by the lenses of literature, learners and autobiography.

Learning activity 3: Expressing learning as a visual narrative in an eposter

Eportfolio lends itself to presentation through a variety of media including text, images, video and audio. These are displayed either on discrete pages, as a Collection (pages with a common theme) or as an eposter. The curating of the eportfolio in terms of design, layout and aesthetics expresses both a narrative of learning as well as a digital representation of the self. The purpose of this learning activity is to use the eportfolio as both a tool (eposter) and a pedagogy (visual narrative of learning).

In a Social Sciences paper, students work in collaborative groups on a community project which involves the key competency: participation and contribution (Ministry of Education [MOE], 2007). Past projects have included cleaning animal enclosures at the zoo, assisting a voluntary organisation, painting a fence in a right-of-way near a local school, and volunteering to working with an environmental group. The purpose of the project, apart from making a community contribution, is for students to stretch their personal learning by setting two key competency learning goals on managing self and relating to others (MOE, 2007).

My input as the lecturer consists of a discussion of key competencies in the Social Sciences and an explanation of the activity. Each student is required to design an eposter in their eportfolio which narrates, through images, the group project experience. Furthermore, they upload a reflective self-assessment of their achievement of their individual learning goals, supported by artefact evidence.

\section{Critical reflection using an autobiographical lens}

Several assumptions were tested in this activity, including my belief that experiential activities can result in deep learning and that group work presents opportunities for personal as well as professional learning. The greatest insight that I experienced during the 2011 self-study was into my assumption that as a teacher I need to be actively involved in working with the students. The fact that students were not dependent on me for their learning was something I knew intellectually but was powerfully made evident through this learning activity. I experienced imposter syndrome (Brookfield, 1994) as I questioned my role and capability as a teacher.

The use of eportfolio as a narrative eposter was based on the assumption that this was a valuable alternative way to express learning. I was unaware of the role of digital (re)presentation of the student 'self' and the impact 
this would have on a student's willingness to make themselves vulnerable to the reader as audience.

\section{Critical reflection using the learners' lens}

Motivation levels were high as one student in 2011 described: "I enjoyed the community project, and this is most probably why I enjoyed displaying it and writing about it and when you enjoy something you learn a lot more from it". Another student talked about how representing learning through images triggered new ways of thinking:

It's really forced me to reflect on how I can show through these images what I can't say...you're having to really think about the images that you put up and what they're reflecting in terms of what I've learnt through the project...'Has this shown how l've worked in relation to my group members and my team?' And so as I'm doing it I have that in my mind and I'm reflecting on that as I go... if someone was to ask me why that's there, I personally want to have a reason.

Some students valued the personal aspect of the eposter: "when you can represent yourself through writing, through text and images, you are able to show the lecturer more of yourself". In contrast, an opposing view highlighted an awareness of a digital identity which can be revealed through eportfolio: "I generally do not like to put anything of myself online, that has always been at the back of my mind".

Engagement in a social pedagogy (Bass, 2014) and the value of drawing on the accumulated knowledge of group members was mentioned: "the use of eportfolio for the group assignment was ideal to synthesise the wide array of learning and evidence from the group", which included group members supporting each other in the achievement of individual learning goals. Students valued the opportunity to display learning through forms other than academic essay writing, to be creative and to personalise their learning: "I feel quite proud of what l've put up...I don't care about the grade because I feel like l've achieved and accomplished something. It was easier to do this than doing essays".

\section{Critical reflection using the lens of colleagues}

Collegial discussion around this activity was positive and supportive, particularly in terms of the value of collaborative groupwork, community contribution and work with a focus on the key competencies. A colleague reported a similar experience of feeling marginalised as the teacher in activities which require students to be autonomous learners. Such feedback was not only professionally reassuring in moderating my sense of the imposter syndrome, but reinforced my assumptions of the value of experiential learning as well as the use of eportfolio to represent this learning in a format different from a written submission.

\section{Critical reflection using the lens of theoretical literature}

Using eportfolio to draw deeply on a student's holistic and personal experience of learning supports the arguments made by Gathercoal et al. (2007) and Hallam and Creagh (2010) for shifting eportfolio use away from a 
focus largely on self-assessment against a set of summative criteria, towards more constructivist learning opportunities. The social pedagogy advanced by Bass (2014) supports collaborative groupwork, as feedback draws from a pool of knowledgeable others and offers students opportunities for deeper learning than would happen if the eportfolio were being used only for individual reflection on achievement. The curating of learning through eportfolio using digital artefacts humanises the presentation by (re)presenting a digital self through the presentation portfolio (in this case an eposter). Cambridge (2009) introduces the concept of a 'symphonic self' to present personal values and synthesised reflection through presentation as relationships and story. His understanding of an integrated portfolio is one which has integrity as it represents the personal and professional self to an audience who read both the content of the portfolio as well as the person behind the presentation. He therefore sees the eportfolio as "the genre at the intersection of two spheres of life, more personal than resume, but more professional than a personal website" (Cambridge, 2008, p. 1239). Integrity comes from negotiating the tension between these two selves, revealing something of the personal self, while maintaining the professional edge.

\section{Evaluation of this learning activity based on the critical reflection model}

Although the literature base on eportfolio for digital narrative of learning is small, it does present a perspective on eportfolio and the digital identity of the author which is revealed through their selection and curating of images and other media. This raises questions around the ethics of the representation of the digital 'self' and its interpretation by a reader. While the autobiographical, collegial and learner lenses are supportive of this learning activity, the literature lens draws attention to the personal/professional tension in the use of eposter to display such learning, as it is the learner who may choose to share more of themselves in the digital presentation than they might do in the objective text of an academic essay.

\section{CONCLUSIONS AND RECOMMENDATIONS}

In this article I have explored three learning activities which use eportfolio, and have built a case for eportfolio to be used both as a tool and a pedagogy. In the first learning activity, the tool function has been emphasised to the detriment of deeper learning which could be triggered through the extension of eportfolio into pedagogy. In the second and third activities, the pedagogical capability of eportfolio outweighs the tool function. Critically reflecting through the four lenses has uncovered perspectives relating to the activities themselves as well as the role of eportfolio in supporting or even enhancing the learning. As a reflective practitioner, I have found this approach particularly enlightening as it has confronted me with assumptions that have informed my practice decisions.

To identify two insights from this reflection: I now more fully understand why using eportfolio with the GTS has never moved beyond a mechanistic level; and I am fully aware of the need to discuss with students the ethics around digital identity and their (re)presentation of the self in electronic narratives. Based on the discussion in this article, I would make the following recommendations for those interested in using eportfolio: 
1. Consider your purpose for selecting eportfolio as a learning tool. It has value when either its tool or pedagogical capabilities align with the intended learning.

2. Constructive alignment of learning outcomes, learning activities and eportfolio purpose will clarify and support student learning experiences.

3. Students need to be aware of the ethics around (re)presenting the self through a digital identity.

4. Seek feedback from students on the value and purpose of eportfolio in learning activities to ascertain whether the intended learning is that which is being received.

5. Critical reflection through the four lenses (Brookfield, 1995) is worth the risk of uncovering assumptions which may disturb the status quo, for what is gained is professional learning to inform practice decisions.

I continue to be an advocate for eportfolio and conclude with a supporting student comment:

I've found that l've gone back to my eportfolio more so than I have done my assignments and essays. I sort of just put them in the box and you know, put them away, but with the eportfolio pages, l've looked at them about 10 times.

With such learner engagement, why would we, as educators, not use eportfolio as a teaching tool and pedagogy?

Manuscript Submitted: November 2, 2015

Revised Manuscript Received: February 9, 2016

Revised Manuscript Accepted: February 11, 2016 


\section{REFERENCES}

Barrett, H. (2010). Balancing the two faces of eportfolio. Retrieved on October 10, 2014 from http://electronicportfolios.org/balance/Balancing2.htm

Bass, R. (2014). Social pedagogies in eportfolio practices: Principles for design and impact. Retrieved from http://c2l.mcnrc.org/wpcontent/uploads/sites/8/2014/01/Bass_Social_Pedagogy.pdf

Baxter Magolda, M. (2014). Self-authorship. New Directions for Higher Education, 166, 25-33. DOI: 10.1002/he.20092.

Biggs, J. (1999). Teaching for quality learning at university. Buckingham, United Kingdom: SRHE and Open University Press.

Boud, D. (2001). Using journal writing to enhance reflective practice. New Directions for Adult and Continuing Education, 90, 9-17. DOI: 10.1002/ace.16

Boud, D., Keog, R., \& Walker, D. (Eds.). (1985). Reflection: Turning experience into learning. London, United Kingdom: Kogan Page.

Brannick, T., \& Coghlan, D. (2007). In defence of being "native": The case for insider academic research. Organizational Research Methods, 10(1), 59-74. DOI: 10.1177/1094428106289253

Brookfield, S. (1994). Tales from the dark side: A phenomenography of adult critical reflection. International Journal of Lifelong Education, 13, 203216. DOI: $10.1080 / 0260137940130303$

Brookfield, S. (1995). Becoming a critically reflective teacher. San Francisco, CA: Jossey-Bass.

Brookfield, S. (1998). Critically reflective practice. Journal of Continuing Education in the Health Professions, 18(4), 197-205. DOI:10.1002/chp.1340180402

Brookfield, S. (2002). Using the lens of critically reflective teaching in the community college classroom. New Directions for Community Colleges, 118, 31-38. DOI:10.1002/cc.61

Bullough, R., \& Pinnegar, S. (2001). Guidelines for quality in autobiographical forms of self-study research. Organizational Research Methods, 10(1), 59-74. DOI: 10.3102/0013189X030003013

Cambridge, D. (2008). Cultural ideals for eportfolio practice: Authenticity, deliberation and integrity. Retrieved on 10/5/2012 from www.slideshare.net/dcambrid/cultural-ideals-for-eportfolio-practiceauthenticity-deliberation-and-integrity?qid=ab4dcde7-6079-4f62-b57d30407df3f964\&v=\&b=\&from searc964\&vh=1

Cambridge, D. (2009). Two faces of integrative learning online. In D. Cambridge, B. Cambridge \& K. Yancey (Eds.), Electronic portfolios 2.0: Emergent research on implementation and impact (pp. 41-49). Virginia, VA: Stylus.

Doig, B., Illsley, B., McLuckie, J., \& Parsons, R. (2006). Using eportfolios to enhance reflective learning and development. In A. Jafari \& C. Kaufman (Eds.), Handbook of research on ePortfolios. Hershey, PA: Idea Group Reference.

Education Council. (2007). Graduating teacher standards. Retrieved from https://educationcouncil.org.nz/sites/default/files/gts-poster.pdf

Emmett, D., Harper, W., \& Hauville, K. (2006). Creating a strategy for the implementation of the QUT eportfolio. In A. Jafari \& C. Kaufman (Eds.), 
Handbook of research on ePortfolios. Hershey, PA: Idea Group Reference.

Eynon, B., Gambino, L., \& Török, J. (2014). What difference can eportfolio make? A field report from the Connect to Learning Project. International Journal of ePortfolio, 4(1), 95-114.

Gathercoal, P., Crowe, J., Karayan, S., McCambridge, T., Maliksi, S., Love, D., \& McKean, G. (2007). Webfolios: Authentic state and accreditation standards. In T. Townsend \& R. Bate (Eds.), Handbook of teacher education (pp. 641-656). Dordrecht, The Netherlands: Springer.

Gerbic, P., \& Lewis, L. (2011). Dimensions of eportfolios: Research perspectives from a teacher education programme. Educational Provocations, 1, 19-34.

Hallam, G., \& Creagh, T. (2010). Eportfolio use by university students in Australia: A review of the Australian Eportfolio Project. Higher Education Research and Development, 29, 179-193.

Joint Information Systems Committee. (2008). Effective practice with eportfolios. $\quad$ Retrieved on 10/3/2016 from www.repository.jisc.ac.uk/5997/1/effectivepracticeportfolios.pdf

Lewis, L. (2013). Social sciences and the key competencies: A practitioner reflects. Curriculum Matters, 9, 64-81.

Lewis, L. (2014). Eportfolio for enhanced learning? Student and lecturer perspectives. Educational Provocations, 46-56.

Lewis, L., \& Gerbic, P. (2012a). The student voice in using eportfolio to address professional standards in a teacher education programme. Journal of Teaching and Learning for Graduate Employability, 3(1), 17-25.

Lewis, L., \& Gerbic, P. (2012b). "It's your spell-checked version of yourself": Student perceptions around (re)presenting self through eportfolio. In ePic eportfolio and identity conference proceedings (pp. 88-93). http://www.epforum.eu/sites/www.epforum.eu/files/ePIC\%202012_0.pdf

Matthews-DeNatale, G. (2013). Are we who we think we are? Eportfolios as a tool for curriculum redesign. Journal of Asynchronous Learning Networks, 17(4), 1-16. Available from http://c2l.mcnrc.org/wpcontent/uploads/sites/8/2014/01/Are-We-Who-We-Think-WeAre 1_6 14.pdf

Merriam, S. B., Caffarella, R. S., \& Baumgartner, L. M. (2007). Learning in adulthood: A comprehensive guide (3rd ed.). San Francisco, CA: JosseyBass.

Milman, N. (2005). Web-based digital teaching portfolios: Fostering reflection and technology competence in preservice teacher education students. Journal of Technology and Teacher Education, 13, 373-396.

Ministry of Education. (2007). The New Zealand Curriculum. Wellington, New Zealand: Learning Media.

Moon, J. (1999). Reflection in learning \& professional development: Theory \& practice. London, United Kingdom: Routledge-Falmer.

Oakley, G., Pegrum, M., \& Johnston, S. (2014). Introducing eportfolios to preservice teachers as tools for reflection and growth: Lessons learnt. AsiaPacific Journal of Teacher Education, 42(1), 36-50. DOI: 10.1080/1359866X.2013.854860

Palmer, P. (1998). The courage to teach: Exploring the inner landscape of a teacher's life. San Francisco, CA: Jossey-Bass. 
Parkes, K., Dredger, K., \& Hicks, D. (2013). ePortfolio as a measure of reflective practice. International Journal of ePortfolio, 3(2), 99-115.

Peet, M., Lonn, S., Gurin, P., Page Boyer, K., Matney, M., Marra, T., Himbeault Taylor, S., \& Daley, A. (2011). Fostering integrative knowledge through eportfolios. International Journal of ePortfolio, 1(1), 11-31.

Pelliccione, L., \& Dixon, K. (2008). ePortfolios: Beyond assessment to empowerment in the learning landscape. Conference Proceedings, Ascilite, Melbourne, Australia. November 30-December 3. Deakin University.

http://www.ascilite.org/conferences/melbourne08/procs/pelliccione.pdf

Ring, G., \& Foti, S. (2006). Using eportfolios to facilitate professional development among pre-service teachers. In A. Jafari \& C. Kaufman (Eds.), Handbook of research on eportfolios (pp. 340-355). Hershey, PA: Idea Group Reference.

Shön, D. (1983). The reflective practitioner. San Francisco, CA: Jossey-Bass.

Stefani, L., Mason, R., \& Pegler, C. (2007). The educational potential of eportfolios. London, United Kingdom: Routledge.

Wetzel, K., \& Strudler, N. (2006). Costs and benefits of electronic portfolios in teacher education: Student voices. Journal of Computing in Teacher Education, 22(3), 69-78. DOI: 10.1080.10402454.2006.10784544 


\section{ABOUT THE AUTHOR}

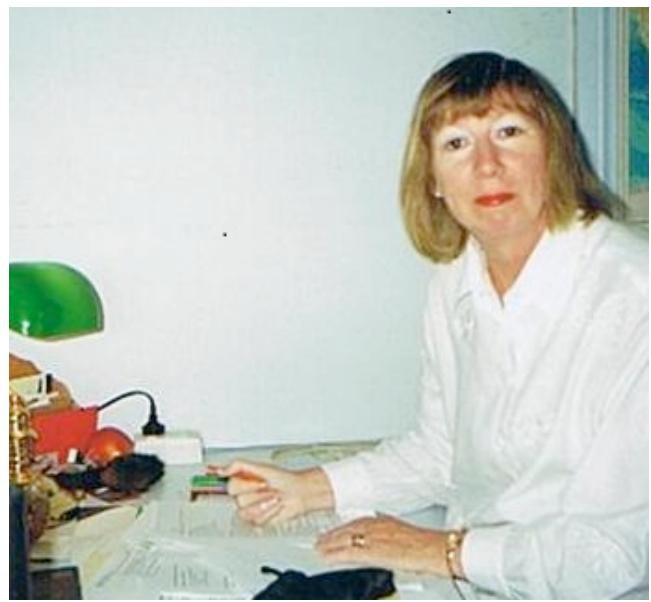

Lyn Lewis is Head of School at Auckland University of Technology and has been involved in eportfolio for learning since 2007. Over the period 2009-2015 Lyn has engaged in research with a focus on student perspectives of learning through eportfolio, and she has published in this area.

\footnotetext{
The opinions expressed are those of the paper author(s) and not the New Zealand Journal of Teachers' Work. Copyright is held by individual authors but offprints in the published format only may be distributed freely by individuals provided that the source is fully acknowledged. [ISSN-1176-6662]
} 